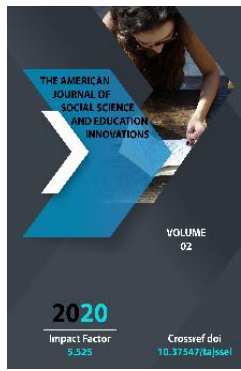

\title{
Abe Tomoji As A Theorist Of Modernism
}

\author{
Abubakirov Javokhir Soatulla ugli \\ The 2nd Year Master Degree Department Of Literature Of Foreign Eastern Countries, \\ Tashkent State University Of Oriental Studies Tashkent, Uzbekistan
}

Journal Website:

http://usajournalshub.c

om/index,php/tajssei

Copyright: Original

content from this work

may be used under the

terms of the creative

commons attributes

4.0 licence.

\section{ABSTRACT}

The studying Abe Tomoji's contribution to the development of Japanese literature and the impact of the socio-political period of his work. This research is to broaden the scope of our knowledge through highlighting the issues and feelings of the events that took place in the life of the country by the Japanese people.

\section{KEYWORDS}

Bungaku no Kousatsu, (Study of Literature, 1934 ) Jyoujyo to hyougen (Lycrism and Expression),and Gendaino bungaku (The modern literature), Bungakuronshyu (Collection of Literary Theories), showa (昭和 ) period-in Japanese history period(1926-89) corresponding to the reign of the emperor Hirohito.

\section{INTRODUCTION}

Although, the time changes, the prospect of the nation's disappearance, first of all, is reflected in the literature. During the study of literature, it is possible to discover the spirit of that nation and its evolutionary evolution. The role of literature is incomparable. In addition to studying foreign languages, studying literature in that language is one of the most important tasks of today. In particular, studying the Japanese literature helps to learn the Japanese mentality. The country's literature is also unique. Studying Japanese literature is not merely a study of the nation's thinking, but a respect for the Japanese nation. The defeat in World War II led to radical changes in Japan, particularly in the socio-political, economic, and cultural life of Japan. Such effects can be seen in the antimilitarist works that emerged after the war. That is, the end of the Second World War, the state of the post-war society has created 
the basis for the creation of antimilitarist artifacts that now deny the new genre war.

Abe Tomoji was a Japanese novelist, social critic, humanist, and translator of English and American literature.

Abe Tomoji wrote numerous essays in his lifetime. They were published in some collections of essays, such as Shuchiteki bungakuron, Bungaku no Kousatsu, Jyoujyo to hyougen (Lycrism and Expression),and Gendaino bungaku (The modern literature). The first collection, shuchiteki bungakuron was developed and organized systematically into Bungakuronshyu (Collection of Literary Theories), which was given the new title Bungaku Nyumon (An introduction to literature) after World War II, and exerted influence on the field of Japanese literature for a long period of time thereafter.

A cursory look at the essays written from 1925 through the 1930s suggests that Tomoji is consistent in his assertion of the importance of "intellect" in literature, and he criticizes sentimentalism and the lack of ideas as a weakness on Japanese literature. His literary theories are based on European ones, but they also derive from his consciousness of his times and his critical spirit.

Because of his effort to intellectualize and articulate the ideas that underlie Japanese literature and what it ought to be, Tomoji became one of the most important theorists of the early shyouwa (昭和) period. In this article we will discuss Tomoji's literary theories from the 1930, when he was held to be a theorist of Modernism.

According to Mizukami Isao, Tomoji's first literary essay was Kyouseishya no tamashi published in 1925 in Shyumon, the literary magazine of the department of literature, Tokyo University. It reflected his basic point of view which would emerge in Shunchiteki bungakuron 5 years later. In this essay, Tomoji adopts an idealistic standpoint social function of literature "Art is rectification that intends to create ideals for society and that stand outside time." He argues that writers should fight against the art of Dadaism and what he calls trivialism by means of appealing to the simple yet serious life, that they should war against the flat trivialism with Romanticism, as well as against normal and common society with its morbid interests in literature. In short, the function of literature is rectification. Moreover, his arguments are clearly dualistic one of the conspicuous characteristics of Tomoji's way of thinking and seeing. As Mizukami points out, the buds of "intellectualism" such as dualism and a critical spirit Tomoji's nature are already to be found in this early sally.

Tomoji's shuchiteki bungakuron was published against the backdrop of a "time of unrest." The Kanto earthquake of in 1923 and the financial panic that swept Japan after World War I shook the foundations of Gijitsushya (The art for art's sake school), and such writers were unable to resist the tide of proletarian literature. The "time of unrest" allowed proletarian literature to gain force and to reach its high point of popularity between 1928 and 1931. This suicide of this prominent writer and advocate for the primacy of art caused Tomoji to fundamentally rethink the relationship of intellect and literature. He felt the need to advance a theory that was formidable enough to support the modernism movement and to criticize the proletarian literary forces that took politics as a top priority. This position was also similar to 
that of Shinkankakuha (new perception school) in its negation of the first novel which had been established by Japanese naturalism.

In this analysis, Mizukami alludes to the intellectual trends which had existed prior to Tomoji's shuchishugi (intellectualism), by pointing out that Akutagawa, Yokomitsu, and Haruyama Yukio were the precursors of Tomoji's "Intellectualism". The intellectual trends in Akutagawa's and Yokomitsu's works lay the foundation for the literature of the Shouwa period and the magazine Shi to shiron (poems and poetics) edited and published by Haruyama, exercised an enormous influence on the structure of literature of the Shouwa period. It was Haruyama who christened "intellectualism" as a literary trend which grew and centered on Shi to shiron, and appropriately enough he titled Tomoji's first collection of essays "A literary theory of intellectualism". Circa 1926 , the literary men who were active in Shin to shiron, including Tomoji, set about introducing literary trends from post World War I in Europe. Among these trends, there was the "Intellectualism" that arose in England and was advanced by T.S. Eliot, Herbert Read, and Aldous Huxley. It was predicated upon the primacy of "intellect" over emotion as well as a return to logic and the classics, especially in the Greco Roman tradition. The chaos that resulted from Romanticism in the 19- century triggered a call to rethink literary concepts and to reestablish the classical "canon".

There was no tradition of role of "intellect" in literary history, Japanese writers lacked an identifiable intellectual tradition to reestablish. But, as the equivalent for the chaos caused by Romanticism in Europe, Japan had "sentimentalism" as it was manifested in naturalist and proletarian literature. Sentimentality was the aspect of Japanese literature that Tomoji set out to consistently negate. Clearly he was attracted to the Intellectualism movement in England, which applied a new rational approach to the study of literary tradition, a clearer analysis of psychology and a sense of distinct modeling.

In his essays Tomoji takes a serious look at the issues of rationality and intellect. He calls for critical observation and description, and the control of emotion by intellect. His chief contention is that, while literature has its own origin in the contra dictions and chaos that reside at the bottom of the human mind, nonetheless, it takes shape when human being give order to the chaos. Therefore, literature is something instinctive which emerges from the chaotic abyss of the human mind, yet only when intellect conquers does literature become art. He tells of the importance of the simultaneous expression of contradiction and order, the value of art which exists in its most chaotic state and in its enormous order, and the meaning of creativity as the force which expresses the deepest chaos within the tightest order. Intellect is not used solely for social or utilitarian purposes. It does not reject emotion, for Intellectualism believes in emotion and hopes for its expansion. For Tomoji the abyss of emotion is understood as having no limitations or any mysteriousness but it should be studied in an intellectual way.

Mizukami points out that Tomoji's arguments were more closely resemble those of Herbert Read's than those of Eliot's. in Herbert theory of intellectualism, there are 2 opposing forces within the literary minds of all artists. One is the primitive spirit which rejects intentional 
controls, and the other is the force which leads strong emotion to order and the establishment of the structure of the ideal. These 2 forces will produce a perfectly harmonious art when they are in equilibrium. On the other hand, Eliot believes in stoic legalism such as negation of emotion or the obliteration of individuality. Because of Tomoji's strong penchant toward dualism and his originally romantic nature, he seemed to find more comfort in adopting Read's ideas.

The brand of "Intellectualism" centered on shi to shiron rapidly disappeared from the literary field since it had difficultly taking root in Japanese literature and society, which is not remarkable for emphasizing rational thought. It was swept aside by the wave of "Jazz culture" coming from America and the hedonism of ero, guro, nansensu(eroticism, grotesque, nonsense). It took several years for Tomoji to take his theory and adopt it into his own work, Fuyu no yado (冬の宿). Nakamura shinichiro suggests that Tomoji's influence still operates in contemporary literature as a kind of common knowledge, and that Tomoji ultimately triumphed even if the rise of militarism erased the rationality of intellectualism.

It goes without saying, that a writer who advocates the social function of literature or the function of intellect in literature would not affirm Naturalism. Tomoji criticized Japanese Naturalism in his essays Riarizmu no mondai (The problem of realism 1932) and Riarizmu to shinjitsu (Realism and truth 1934).

In the 1930, as Shinko geijitsushya went into decline, Naturalism regained its force and revived the intellectual -novel, or mind state novel. Opposed to this trend, Tomoji points out in his essay Bungaku no kakumei nit suite
(On the revolution in literature 1932) that the trend of valuing intellectual novel and mental state novel, is strongly connected to the admiration of what is traditional to Japan, and it has caused a stagnation of literature. Then he criticizes Realism in a concrete manner in "The problem with realism" Tomoji argues that the problem with realism lies in the fact that it rejects ideas and concepts of laws and believes instead in experience with material objects, concrete embodiment of feelings, and specificity as manifestations of the real. In realism everything should be reenacted as it is without viewing it from the point of interpretation, values, or ideals, it is to be depicted through the direct reflection of sensation and emotion. Tomoji's discussion on realism allows us to see the fundamental contradiction inherent to the literature of realism. It is by the process of describing through direct reflection of sensations and emotions that writers easily lose their objectivity and the very scientific attitude upon which realism is predicated.

In "Realism and truth" Tomoji dealt with the question of the nature of truth, and how writers could express reality through the modern novel. He doubted that the individual believed to have seen as the truth necessarily coincided with temporal phenomena. Thus he decided that no matter how successfully writers made facts look like the truth, in the end of novels remained fictional creations. Therefore, he states that the kind of literature called the I-novel, mental state novel or the personal novel cannot be said to grasp the truth, nor have they described on paper the exact nature of reality.

To challenge the counter argument from the naturalist that one can write through one's 
own eyes, Tomoji introduced the words of the French critic, Henri Massis (1886-1971). Massis wrote the nature of a "real novel" that even if a writer exposed himself with the determination of making a confession, the real novel revealed one's true soul in a more complete and deeper way. The real novel for Massis, in Tomoji's understanding, is in the direction in which writers advance from a particular case to an objective one, from autobiography of the facts to that of possibility. Massis statement is his challenge toward the nature of reality.

\section{REFERENCES}

1. Abe Yoshio, ed. Abe Tomoii kenkvu: shiro kara no teqami.しろからの手紙 Himeji: Abe Tomoji kenkyukai. Vol.I (1994), Vol.2 (1995), Vol.3 (1996), Vol.4 (1997).

2. "Chichi to Showa bungaku." Showa bunqaku kenkvu.昭和文学研究 (July 1990): 63-72.

3. Funabashi Seiichi and Hirano Ken. "Taidan: Abe Tomoji to sono jidai: Abe Tomoji tsuito tokushu." Bunqei.

Vol.12, no.7 (1973): 260-86.

4. Himeji bungakkan, ed. Abe Tomoii: iojo to kodo: showa no sakka. Himeji: Himeji Bungakkan, 1993.

5. Mizukami Isao. Abe Tomoii kenkvu. Tokyo: Sobunsha, 1995.

6. Nakamura Shin'ichiro. "Waga Abe Tomoji: sono n'ingen to bungaku o kataru." Bankaru. (Apr. 1994): 9-20.

7. Nakano Yoshio. "Abe Tomoji: hito to sono shigoto to." Sekai. No.333 (Aug. 1973): 323-29.

8. Yusupovich, K. S. (2020). The Emergence Of Religious Views Is Exemplified By The Southern Regions. The American Journal of Social Science and Education Innovations, 2(10), 143-145.

9. Ярашова, Н. Ж. (2019). ПРОЯВЛЕНИЕ ИНТОНАЦИИ У ДЕТЕЙ ПОСРЕДСТВОМ ОБРАЩЕНИЯ. In ТРадициИ И НОВациИ В профессиональной подготовке и деятельности педагога (рр. 128-130).

10. Jumaevna, Y. N. (2020). Occupation of the child's personal mental status in dialogual speech. Asian Journal of Multidimensional Research (AJMR), 9(5), 405-408.

11. Jumayevna, Y. N. (2019). Linguo culture logical features of metaphors in children's literature (On the example of khudayberdi tokhtabayev's creative work). ACADEMICIA: An International Multidisciplinary Research Journal, 9(4), 139-145. 